\title{
Duyguların Tarihsel Serüveni ve Tarihte Duygular ${ }^{1}$
}

\author{
DOI: 10.26466/opus.876932
}

\author{
Şeyda Koçak Kurt* \\ * Dr., Hacı Bayram Veli Üniversitesi, İletişim Fakültesi, Ankara/Türkiye \\ E-Posta: seydak@gmail.com \\ ORCID: $\quad \underline{0000-0003-2797-1424}$
}

\section{Öz}

Duygular uzun yıllar psikolojinin alanında görülmüş ve bireye özgü olarak ele alınmıştır. Duygunun tarihine bakıldığında ise pek çok filozof, sosyolog, antropolog ve tarihçinin ana çalışma konusu olduğu görülmektedir. Bu çalışmada nitel araştırma yöntemlerinden tarihi araştırma yöntemi kullanılarak, duyguların tarihsel seyir içinde nerede yer aldığııı keşfetmek ve toplumsal ilişkilerdeki önemini ortaya çıkarmak amaçlanmıştır. Yapılan tarihi araştırmaya göre; Antik Yunan'da duygular daha çok erdem kavramı çerçevesinde ele alınırken, Orta Çă̆ ile birlikte akıl-duygu ikiliğinin sinırlarının keskin bir şekilde çizilerek, duygunun kilisenin boyunduruğu altına girdiği ve günah kapsamında sayıldığı, 17. yüzyılda kolektif duygulardan bahsedilerek toplumsal ilişkileri düzenlemedeki önemli rolünün vurgulandığı, modernleşme süreci ile birlikte belirli duyguların belirli çevrelere özgü olarak görüldü̈̆̈̈, 20. yüzyılda ise bireyselleşen duygularm dijital teknolojiler ile kapitalizmden bağımsız görülemeyeceği üzerinde durulmuştur. Sonuç olarak; tüm dönemlerde, sanılanın aksine duyguların bireysel alana hapsedilmesinden çok, toplumsal ilişkileri düzenlemede anahtar öneme sahip olduğunun, geçmişten günümüze disipline edilmesi, ehlileştirilmesi ve kontrol altında tutulmasının ön plana çıktığı görülmüştür.

Anahtar Kelimeler: Duygu, duygular tarihi, Aristoteles, duygusal emek, duygusal kapitalizm.

\footnotetext{
${ }^{1}$ Bu çalışma, Gazi Üniversitesi Sosyal Bilimler Enstitüsü Gazetecilik Anabilim Dalı'nda yapılan "Sosyal Medya ve Duyguların Sosyalliği: Suriyeliler Özelinde Facebook Üzerine Bir Inceleme" isimli doktora tezinden türetilmiştir.
} 
ISSN:2528-9527

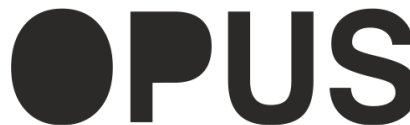

Uluslararası Toplum Araştırmaları Dergisi International Journal of Society Researches
E-ISSN: 2528-9535

Yıl Year. 11

Cilt Volume: 18

Sayı Issue :40

Ağustos August 2021

Makalenin Geliş Tarihi Received Date: 08/02/2021 Makalenin Kabul Tarihi Accepted Date: 12/05/2021

\title{
The Historical Adventure of Emotions and Emotions in History
}

\begin{abstract}
Emotions have been seen in psychology field for many years and handled specifically to individual. Considering emotion's history, it's seen as main subject of many philosophers, sociologists, anthropologists and historians. In this study, using historical research method, one of qualitative methods, it's been aimed to discover the place of emotions in historical course and to reveal its importance in social relations. According to the historical research; In Ancient Greece, while emotions were considered within framework of virtue concept, with Middle Ages, boundaries of the mindemotion dichotomy drawn sharply and the emotion was in the grip of the church and considered as sin, and in 17th century, collective feelings were mentioned and its import role in organizing social relations was emphasized, with modernization process, certain emotions were seen as specific to certain environment, in 20th century, it was emphasized individualized emotions can't be seen as free of capitalism with digital technologies. As a result; contrary to popular belief, in all periods, it's been underlined emotions have a key importance in organizing social relations and should be disciplined, tamed, kept under control from past to present rather than confining to individual sphere.
\end{abstract}

Keywords: Emotion, history of emotions, Aristoteles, emotional labour, emotional capitalism. 


\section{Giriş}

Duygu (emotion) kavramı, hareket etmek, dışarı çıkmak anlamlarına gelen Latince bir kelime olan 'emovere' kelimesinden türemiştir ve duygunun bireyler, toplumlar, topluluklar arasında hareket halindeki yapısına gönderme yapmaktadır (Ahmed, 2014, s21). Tarihsel olarak her daim üzerinde durulan bir kavram olmakla birlikte duygunun "emotion" olarak İngilizce konuşan yazarlar tarafından kullanılmaya başlanması ise 19. yüzyıl gibi geç bir döneme rastlamaktadır (Frevert, 2016, s.49). Bu döneme değin daha çok psikolojik temelli ele alınan duyguları teorileştirebilmek için birden fazla kavram kullanılmaktadır. Bu kavramlar arasında "tutku" (passion), "haz" (pleasure), "sezgi" (sentiment) (Dixon, 2012, s.340), "arzu" (desire), "duyum" (sense), "duygulanım" (affect) (Frevert, 2014, s.52) ya da "ruh kazaları" (accidents of the soul), "ahlaki hisler" (moral sentiments) (Watt Smith, 2018, s.16) gibi çeşitli kavramlar yer almakta ve bugün duygu denince anlaşlan şeyden çok farklı anlamlar içermektedir. Plamper'a göre (2015, s.11); 1872 ve 1980 yılları arasında doksan iki adet farklı duygu tanımı yalnızca İngilizce deneysel psikoloji alanında kullanılmıştır. Ayrıca İngilizce literatüre bakıldığında duyguları tanımlamak için "emotion" (duygu) kavramının yanında, "affect" (duygulanım), "feeling" (his) gibi farklı kavramlar kullanıldığı görülmektedir (Tenhouten, 2007, s.2).

Duygunun kavramsal kullanımı üzerinde ortak bir görüş olmayışı, eski çağlardan itibaren duygunun üzerinde durulmadığı anlamina gelmemektedir. Zira farklı kavramlar ve anlamlar altında olsa dahi her dönemde duygular pek çok filozof, psikolog, sosyolog, antropolog ve tarihçiler gibi farklı bilim dallarına mensup kişilerin merak ve araştırma konusu olmuştur. Duygunun farklı kavramlar altında kullanılması, duygunun zaman içerisindeki anlam farklılaşmasını göstermesinin yanı sıra, aynı dönemde farklı coğrafyalarda farklı anlamların kullanıldığına da işaret etmektedir. Örneğin; günümüzü kapsayan modern çağda "mutlu olmak" genellikle ulaşılması gereken bir hedef olarak görülürken, Mikronezya'daki Ifaluk kültüründe mutluluk; gösteriş, aşır1 heyecan ve görevlerini yerine getirmemeye sebep olduğu için teşvik edilmemektedir (Lutz, 1987, Watt Smith, 2018, s.192). Aynı şekilde Batı ve Doğu toplumlarında kişilerarası ilişkilerin mutluluğu yakalamada 
önemli bir faktör olduğu kabul edilmekle birlikte, iki toplumun mutluluk kavramları arasında keskin ayrımlar olduğu görülmektedir (Joshanloo, 2013). Duygunun anlamının zaman içerisinde değişmesi konusunda "üzüntü" duygusunun 16. yüzyıldaki yansımasına bakılabilir. Bu dönemde "üzüntü"nün ya da mümkün olduğunca "üzgün olmanın" kişinin karakterini ağırlaştırdığı ve dirençli ve kararlı olmakla eş tutulduğu görülmektedir (Watt Smith, 2018, s.277). Bu durum, duygulara yaklaşım şekillerinin de farklılık göstermesini beraberinde getirmiştir. "Nostalji" duygusu, bugün geçmişe özlem duymak anlamında kullanılmasına rağmen, 17. yüzyılda tıp alanı tarafından incelemeye tabi tutulmuş bir hastalık olarak ele alınmıştır. Özellikle Avrupa'daki savaşlar nedeniyle pek çok askerin "nostalji salgınına" yakalandığını söyleyen Boym (2009, s.26-27); evlerine dönmek isteyen askerlerin gösterdiği fiziksel rahatsızlıkların (mide bulantısı, iştah kaybı, yüksek ateş vb.) sülük, merhem, afyon ve mide temizlenmesi gibi yöntemlerle iyileştirildiğini anlatmaktadır. Nostaljinin o dönemde farklı anlamlar ve yaklaşımlar nedeniyle bir "hastalık" olarak, bugün ise "sıla hasreti2" olarak duygu kapsamında ele alınması, duygular tarihi açısından duygunun sabit bir anlamı olmadığını, aynı zamanda duygulara yaklaşımların dönemsel olarak farklılaştığını göstermektedir. Özellikle felsefi açıdan düşünüldügünde, duyguların ne olduğu sorusuna verilen cevaplar zaman içerisinde önemli ölçüde değişmiştir (Plamper, 2015, s.32).

Araştırma, bu bağlamda farklılaşan anlamlarını görmek ve farklı dönemlerde nasıl ele alındığını incelemek maksadıyla duygunun tarihsel seyrine bir bakış sunmaktadır. Ayrıca, yalnızca psikolojinin alanında ve kişiye özel olarak düşünülen duyguların, toplumsal ve kültürel süreçler yoluyla ne şekilde biçimlendirildiğini, deneyimlendiğini ve yorumlandığını ortaya çıkarmak amaçlanmaktadır.

\footnotetext{
2 Yunanca nostalji kelimesi, kelimenin tam anlamına bakarsak yuva hasreti çekme anlamına gelir (Toohey, 2014, s. 131). Buradan zaman içerisinde kelimenin anlamında değil, duygunun anlamında değişiklik olduğu söylenebilir.
} 


\section{Yöntem}

$\mathrm{Bu}$ çalışma duygunun tarih içerisindeki değişen anlamları ve ne tür duygulara yer verildiğini betimleyebilmek açısından alanda yapılmış çalışmaların bir derlemesini yapmaktadır. Çalışma Avrupa'da yapılmış ve İngilizce temelli metinleri ele aldığından Avrupa merkezli bir literatür çalışmasını içermekte ve bu tür bir bakış açısını sunmaktadır.

Mills'in (2016, s.14) ifadeleriyle "insanların kendi yaşam örüntüleriyle dünya tarihinin seyri arasındaki karmaşık bağıntıların farkında olmak", insanların dönüşmekte oldukları tipleri ve kendilerinin de rol alabilecekleri tarih inşası açısından ne anlama geldiğini bilmektir. Bu bağlamda çalışmada; tarihi olarak başlarda öznel bir durum şeklinde ele alınan duygulara yaklaşımın zaman içerisindeki değişimini ve bu değişimin bireylerde ve toplumlardaki geri dönüşlerini inceleyerek bu bağıntıları fark etmek, duyguların tarihi olarak ve günümüzde ne ifade ettiğini ve neler yaptığını görmek amaçlanmaktadır.

\section{Antik Yunanda Duygular}

"Duygu" kategorisinin kendisi görece yeni olsa da hemen hemen eşdeğer terimler - devinimler, duygulanımlar ve tutkular gibi - antik Yunanlılar zamanından beri Batı dillerinin bir parçası olmuştur (Rosenwein ve Cristiani, 2019, s.21). Düşünceler, doğrudan “Duygu nedir?" sorusu etrafında örgütlenmemiş olsa da bu dönemde filozoflar özellikle insana dair değerlendirmelerinde bu konuyu ele almışlardır (Gökalp, 2019, s.14).

Antik Yunan duygular teorisine bir bakış sunan pathos kavramı (Frevert, 2016, s.50), duygular tarihi açısından incelenmesi gereken bir önemdedir. İngilizce'deki 'emotion' (duygu) şeklinde yorumlanabilen pathos, (çoğulu pathe) 'öfke' (anger), 'korku' (fear), 'aşk' (love) 'acıma' (pity), 'kızgınlık' (indignation), 'kıskançlık' (envy) ve benzeri şekilde çevrilebilen bir dizi terimi içermektedir (Konstan, 2006, s.29-30). Akılruh ikiliğinin ön planda olduğu bu dönemde, duygulardan ziyade ruhtan bahsedilir ve ruhun istekleri bedenle ilişkilendirilirken, Platon ve Aristoteles duyguları bu şekilde ayırmadan, bizi beden ve zihin, biliş ve arzu, alg1 ve hisi içeren bileşimsel karmaşıklıklar konusunda uyarmakta; 
duygular, beden ve ruh, alg1, hayal gücü, duygu ve düşünme arasındaki karşılıklı bağlantıları benimsemektedir (Price, 2009, s.123). Platon'a göre, tüm coşku ve istekler ölümlü olan bedene ait özellikler olarak görüldüğü için onlardan kaçınılması, uzaklaşılması tavsiye edilmektedir (Gökalp, 2019, s.17). Bilgi, hele kesinliğiyle ya da iyi ve hayret uyandırıcı şeyleri konu alışıla üstün olan bilgi güzel ve değerli şeyler arasında sayılmakta (Aristoteles, 2019b, s.31); bilgi ile bütünleştirilen akıl her şeyin üstünde tutularak bilgiye ulaşmayı engelleyecek tüm ruhsal istekler ve hazlardan uzak durulması salık verilmektedir.

Antik dönem duygularını modern bir bakış açısı sunarak ayrıntılı bir şekilde inceleyen en önemli isimlerden biri Aristoteles'tir. Platon'un pathos'unun Aristoteles'in 'duygulanım' anlamındaki pathe'sine (pathos'un çoğulu) öncülük ettiği ve kavramın tanımlamalarının daha açık şekilde yapıldığı (Cluzeau, 2013, s.65-66) görülmektedir. Siyasi retorik aracılığıyla, duyguları ve tutkuları tetikleyerek dinleyicilerin harekete geçmesinin mümkün olduğuna dair düşünceleri Aristo'ya dek götürmek mümkündür (Plamper, 2015, s.132). Antik dönem duygu tanımlamalarından en etkilisini Aristoteles, Retorik'in ikinci kitabında yapmiştır (Konstan, 2018, s.46). Pathé dediği ve öfke, aşk, nefret, korku, utanç, kıskançlık, minnet, şefkat, kızgınlık içeren bir dizi duygunun yanında zélos dediği (İngilizce'deki zeal -heves/şevk - ve jeaolusy kıskançlık - kavramlarının birleşimi) rekabetçi bir tutkudan bahsetmektedir. Aristoteles, Retorik (1995) isimli eserinde, bir ikna etme yöntemi olarak hitabetin nasıl yapılacağını anlatır. Bunu anlatırken de duyguların çok önemli işlevlere sahip olduğunu söylemektedir. Retorikte esas olan, dinleyicilerin / izleyicilerin duyguların harekete geçirmektir. Ona göre, öfke, acıma, korku ya da karşıtlarını içeren pathos, kişinin yargısını etkileyerek içinde bulunduğu durumu dönüştürme gücüne sahiptir (Frevert, 2016, s.50). Aristoteles'in duygu yaklaşımında karşılıklı etkileşim ön plana çıkmaktadır. Toplulukları ikna yöntemi olarak duyguların kullanılmasından bahseden Aristoteles, aslında özellikle politik konuşmalardaki duygusal manipülasyonun içeriğine dikkat çekmektedir. Konuşmacının başarılı olabilmesinin çok önemli bir koşulu, dinleyicide istediği duyguları yaratabilmesidir.

Aristoteles'te bedenden ziyade insan yargıları öne çıkmaktadır (Rosenwein ve Cristiani, 2019, s.35). Bu da beraberinde "erdem" ve 
"ahlak" kavramlarını getirmektedir. Aristoteles'e göre (2019a, s.29); erdemin ne olduğunu bilmek, ruhta meydana gelenleri bilmekten geçmektedir. Acıdan sakınıldığı, zevkin ise peşine düşüldüğü için acı dolu olan ile zevk dolu olan neredeyse her zaman birbirlerine eşlik etmektedir (C. Nussbaum, 1978, s.44). Ac1 ve hazzı getiren duygular konusunda "orta" olmak ne çok fazla acıya maruz kalmak, ne de tümüyle hissizleşmek anlamına geldiğinden iyi durumda olduğumuzu göstermektedir. Çünkü duyguların yoğunluğu yahut eksikliği insanın erdemli ve ahlaklı olmasının önündeki engeller olarak görülmektedir.

Bir yandan tutkular ve arzular, öte yandan daha hafif hisler ve duygular arasındaki önemli ayrımı anlamak için Stoacılık ve Hristiyanlık arasındaki tartışmalara bakmamız gerektiğini söyleyen Dixon (2012, s.339), Stoacıların bütün tutkulara ruhun hastalıkları olarak davrandığını ve bilge bir insanın mantığa başvurarak kendisini tedavi edebileceğini düşündüklerini aktarmakta, fakat yine de eupatheia olarak bilinen daha hafif olumlu duygularla zihnin tutkularından ve tedirginliklerinden kurtulmak için bir tür bilişsel terapi kullanmayı amaçladıklarını eklemektedir. Stoacılar duyguların kökünden sökülüp atılması ve kişilerin kendilerini her türlü duygu ve arzudan azade etmesi gerektiğini düşünmektedirler (Oatley, 2004, s.47). Ancak Yunanların pathos kavramından beslenen Stoacı filozoflar, bu kavramın insanların hayatında önemli bir yere sahip olduğunu düşünüyorlardı. Bu nedenle Stoacılar'ın duygulardan kesinlikle uzak durulması gerektiğini söyleyenler ve iyi ve kötü pathos arasında ayrım yapılması gerektiğini söyleyenler olarak kendi aralarında ikiye bölündüklerini söylemek mümkündür. Neşeye boyun eğin ama şehvetten uzak durun; korku dolu olmak yerine sağduyulu olun, mantıklı bir istek için arzuyla savaşın gibi (Frevert, 2016, s.51). Stoacılar için önemli olan "tutku" olarak adlandırdıkları tehlikeli duyguların kontrol altında tutulması idi. Onlar; ensedeki tüylerin ürpermeye başladığı ilk an yakalanırsa, kör bir paniğe kapılmamak konusunda insan kendini ikna edebilir diye düşünüyorlardı (Watt Smith, 2018, s.23-24). Antik Yunan'da duyguları farklı kılan; bireyin alanından çıkarak kamu ve özel arasındaki sınıra rağmen agoralar vasıtasıyla duyguların kamusal bir alana taşınmasıdır. Örneğin bir Yunan tragedyasının izleyicileri, oyundaki karakterlerin dişa vurduğu duyguları hayali biçimde kendilerine uygularlar (Rosenwein ve 
Cristiani, 2019, s.154). Orta Çağ üzerine yazılmış Batı literatürüne bakıldığında ise, duyguların önemi vurgulanmakta ve duyguların cinsiyetlendirilmesine tanık olunmaktadır.

\section{Batı Literatüründe Orta Çağda Duygular}

Orta Çağda kilisenin yaşayış üzerindeki etkisini ve bilginin tek elde toplanmasını konu edinen Eco'nun Gülün Adl (2013) romanı, Aristoteles'in yazdığı, tek kopyası olan ve ne yazık ki günümüze ulaşamamış eseri Poetika'nın ikinci cildinin, yalnızca güldürü ve gülmeyi işlemesi sebebiyle ortadan kaldırılmaya layık görülmesini anlatmaktadır:

"Birinci kitapta tragedyayı ele almış, acıma ve korku esinleyerek, nasıl bu duygulardan arınma sağladığını görmüştük. Söz verdiğimiz gibi şimdi de güldürüyü (aynı zamanda hiciv ve mimi) ele alacak ve gülünç olandan zevk almayı esinleyerek, bu duyguyu sonunda nasıl arıttığını göreceğiz"' (Eco, 2007, s.586).

Buna göre, gülmek eylemi ve beraberinde gelen mutluluk en büyük kötülüklere sebep olacaktır. Şehvet ve zalimlik emaresi saydıkları kahkaha ve şakaları, genellikle uygun görmemişlerdir (sonuçta İsa Kitabı Mukaddes'te bir kez bile gülmez) (Watt Smith, 2020, s.88). Bu dönemde özellikle dini duygular kilisenin etkisi ile ön plana çıarak insan zihninden ve bedeninden uzak tutulması gereken şeyler olarak görülürken, ayn zamanda insan bedeni ve ruhun duygudan azade olmadığına yönelik görüşler bulunmaktaydı.

Orta Çağ duygu tarihçilerinden Rosenwein, bu dönemin tek bir duygusal dönem olarak ele alınmasına karşı çıkmaktadır. Yalnızca 6. yüzyıldan 7. yüzyılın sonlarını içeren çok kısa bir zaman diliminde bile, duygusal kelime dağarcığının ve ifade şekillerinin değiştiğini vurgulayan Rosenwein (2006, s.2), bu sonuca varabilmek için bağlamı "Orta Çă̆" veya "modern" ayrımindan kurtararak "duygu topluluklarından" (emotional communities) bahsetmektedir. Buna göre "duygu toplulukları", duygusal dişavurumun belirli duyguları, hedefleri ve normlarının aynı ya da benzer değerlemelerini paylaşan insan gruplarıdır (Rosenwein ve Cristiani, 2019, s.17) ve bu topluluklar birden fazla olabilir, eşzamanlı olarak var olabilir ve zamanla değişebilir (Rosenwein, 2006, s.2). Dolayısıyla bu dönem için keskin ayrımlardan 
bahsetmek olası değildir. Bir yandan din alanında baskı altına alınan yahut ön plana çıkarılan duygularla karşılaşabilirken, öte yandan duyguların farklı topluluklar tarafından farklı şekilde paylaşıldığına rastlanmaktadır. Bu bağlamda Orta Çağ duyguların hem gün yüzüne çıktığı hem de bir o kadar bastırılmaya çalışıldığı bir dönem olarak tasvir edilebilir. Mantık-erkek, duygu-kadın algısının da aynı zamanda vurgulandığ 1 bir dönemdir. Cinsiyetlendirmeyle ilgili olarak Rosenwein, özellikle Orta Çağ'da kadınlara yönelik pek çok ayrımcı bakış açısının hüküm sürdüğünden bahseder. Çocuk sahibi olan kadınların acıyla karşılaşınca çığlık atma izinlerinin olduğunu söyleyen Rosenwein (2002, s.844); ideal kadının ise, acı çeken İsa'yla özdeşleşmenin bir işareti olarak, acıyı şikâyet etmeden minnetle karşılayan kişi olduğunun altını çizer. Duyguların cinsiyetlendirilmesi bu dönemde daha keskin bir şekilde görülmektedir³.

Fransiskenli bir rahip olan Thomas Aquinas, 13. yüzyılda duygulanımlar ve tutkular hakkında etkileyici görüşlere sahiptir. Passiones (tutkular) kavramını, bedensel dönüşümün eşlik ettiği aktif duyusal arzular olarak tanımlayan kolektif bir terim olarak seçen Aquinas, tutkulara kötücül bir nitelik yüklememekle birlikte, yine de iradeyi her şeyin üzerinde tutmakta ve tutkuların kalıba konularak, düzenlenmesi ve yönetilmesi için iradeye ihtiyaç olduğunu belirtmekteydi (Frevert: 2016, s.51). Akıl, kişileri düzen içerisinde tuttuğu müddetçe erdemli olunabilirdi.

Aquinas gibi Augustine de duygular ve düşüncelerle ilgilenmiştir. Augustine'e göre korkudan titremeyen ya da hüznün acısını çekmeyen bir kişi gerçek huzuru bulamaz, tüm insanlı̆̆ kaybederdi (Augustine'den akt. Dixon, 2003, s.29). Ancak Augustine de duygular1 ruha ait görmekte ve bedensel arzuya yol açan ruhun tutkularının hatalar ve yanlış fikirler ile yaşamı kirlettiğini (Augustine, 2010, s.101) düşünmektedir. Augustine ve Aquinas gibi Latince yazan Hristiyan yazarlar insanların ne hissettiği konusunda nasıl düşünmek gerektiğiyle ilgili temel düşünceleri ortaya attılar ve bu düşünceler Avrupalılar

\footnotetext{
3 Bununla birlikte, bu durum Aristoteles zamanında da görülmektedir: "Kadın erkekten daha merhametlidir, daha çabuk gözleri yaşarır. Aynı zamanda daha kıskançtır, daha çok sızlanır, azarlamaya ve bağırıp çağırmaya daha eğilimlidir. Ayrıca, ümitsizliğe düşmeye daha yatkındır ve erkeğe göre daha az umutludur (Aristo'dan akt. Brownmiller, 2013, s.387).
} 
tarafından 18. yüzyıla kadar kullanıldı. Ancak bu kez de duyguların din alanına girişi ve oradan çıkamayışına tanık olunmaktadır. Hristiyanlık, duyguların din alanında sıkışmasına ve anlamsal olarak mantığın karşısına oturtulmasına neden olmuştur. Aydınlanma ile birlikte ise aklın kutsallaşması iyice keskinleşmiş ve akıl ve hisler arasındaki keskin ayrım, duyguların mantıksız, akıl dışı ve kimi zaman gereksiz olarak görüldüğü bakış açısını perçinlemiştir (Plamper, 2015, s.24).

\section{Aydınlanma Çağında Duygular ve Duyguların Rasyonelleşmesi}

Aydınlanmanın tarihi bilim, rasyonellik, toplumsal sözleşme ve doğal haklarla temsil edilen bir döneme işaret etmektedir (Reddy, 2004, s.142). $\mathrm{Bu}$ dönemde aklın ve bilimin ön plana çıkmasının yanında, ruh ve beden arasındaki ilişkiyi duygular açısından inceleyen isimlerden biri Descartes idi. 17. yüzyıla gelindiğinde Descartes, tutku meselesine farklı bir bakış açısı kazandırmıştır. Les passiones de l'âime dediği "ruhun tutkuları" kavramıla ruh ve beden arasında harekete geçirici bir dinamik olarak tutkuları ele almış, beden ve duygular arasında bir bağ kurmuştur. "Düşünmek nedir?" diye soran Descartes; “Düşünmek sadece anlamak, istemek, hayal kurmak değil, aynı zamanda hissetmektir (sentir)" diyerek, düşünce nosyonuna ilk kez "duygusal" bir boyut getirmektedir (akt. Baker, 2014, s.68). Duyguyu ruha ait olarak ele alan Descartes, duygular1 "ruhun heyecanları" (Descartes, 2017b, s.45) olarak tanımlamaktadır. Descartes'a göre (2017a, s.11) ruhun tutkularını tanımak için, onun işlevlerinin bedeninkilerden ayırt edilmesi gerekir. Yani "duygular, ruhun algılarıdır ya da ruhun hisleri veya heyecanlarıdır" (Descartes, 2017b, s.44). Ruhta tutku olanın bedende eylem olduğunu belirten Descartes, ruh ve bedeni kesin bir çizgiyle ayırmakla birlikte, ruhun bedenle yakın bir ilişki içerisinde olduğunu belirtmektedir. Descartes'ın gerçek bir yenilikçi olduğunu söyleyen Plamper (2015, s.18); modernitenin en etkileyici filozoflarından biri olmasının yanı sıra, akıl-beden düalizminin ötesinde aynı zamanda duygu ve mantık düalizmini de ortaya atarak düalizmin kurucusu sıfatını taşıdığından bahsetmektedir. Plamper'a göre (2015, s.19); Descartes Tanrı'yı rasyonelleştirerek ve onu mantığın özü yaparak açık bir şekilde Augustine ve Thomas Aquinas gibi Hristiyan filozoflardan 
kendisini ayırmış, Tanrı'yı duygu ve mantıkla bezemiş ve aynı zamanda duygunun bedenle olan ilişkisinin göz ardı edilemeyeceğini savunmuştur.

Aydınlanma Çağı boyunca, akılla birlikte ön plana çıkan bedenle ilgili gelişmeler, tıp doktorları ve bilim insanları tarafından artan bir ilgiyle karşılanmıştır. Orta Çă̆'da bazı tutkular ve duygular, bedene zarar veren ve bedeni hasta eden ölümcül günahlar ${ }^{4}$ olarak görülürken, Aydınlanma döneminde beden duyguların bulunduğu yer olarak ön plana çıkmıştır. 18. yüzyıla gelindiğinde artık duygular olmadan bir insanın makineden farksız olmayacağı konuşulmaktadır. Frevert, (2016, s.51-52); 1765 yılında Fransız ansiklopedi yazarlarının la sensibilitê (duyarlılık, hassasiyet) kavramını insanlığın anası olarak belirlediğinden bahsetmektedir. Belirli hisler diğerlerinden daha yaralayıcı olsa da her biri insan yaşamını heyecanlı ve yaşamaya değer kılmaya katkı sağlamaktadır düşüncesi hâkim gelmiştir. Hatta tutku insan kalbini ve zihnini tamamen tüketse bile, önünde sonunda kişinin mutluluğunu ve toplumun genelinin refahını arttırdığ1 düşünülmektedir (Frevert, 2016, s.52).

Orta Çağ'da duyguların "çocuksu" ve mantık dişı görülmesiyle kıyaslandığında, duyguların ciddiye alınması anlamında epey bir yol kat edildiğini söylemek mümkündür. Rosenwein da (2002, s.827); Orta Çağ'da çocuksu bir duygusal yaşam olduğunu, modern çağda ise özdisiplin, kontrol ve baskılamanın söz konusu olduğunu belirtmektedir. Yani Batı' nın tarihi, artan bir duygusal kısıtlamanın tarihidir.

Elias'ın Hitler Almanyası'ndan kaçtıktan sonra 1939 yılında yazdığı "Uygarlık Süreci" isimli iki ciltlik eseri, dünyadaki uygarlaşma ve modernleşme sürecini ele almakta ve bunu yaparken duyguların da bir uygarlaşma sürecinden geçtiğinden bahsetmektedir. Fransa'daki soyluluk, krallık ve saray toplumu üzerine hazırlamış olduğu doçentlik tezini temel alan Elias (2017, s.69); Orta Çağ'dan uygarlaşma sürecine,

\footnotetext{
${ }^{4}$ Burada ölümcül günahtan bahsederken Frevert, "acedia (asidiya)"yı örnek verir. Uykusuzluk, ateș, ağrı, dizlerde yorgunluk gibi fiziksel özellikleri içeren bu durumda, şeytanın varlığının harici etkilerle gelerek bedene yerleştiği, onu dönüştürdüğü düşünülür. Ruh yeterince güçlü değilse, bedeni bu tür etkilerden koruyamaz ve kişi şeytani bir hastalığa yakalanır. Bu da o kişinin Tanrı'ya olan inanç ve bağlıı̆ııın yeterince güçlü olmadığı şeklinde yorumlanır (Frevert, 2016, s.54). Acedia ile ilgili ayrıntılı bilgi için bkz. Watt Smith, T. (2018) ve Toohey (2014).
} 
Batı'nın davranış biçimlerinden yola çıkarak uygarlaşmayı metinler, anlatılar ve tablolar üzerinden sorgulamış, bunu yaparken de duyguların da değişime uğradığı gerçeğini göz ardı etmemiştir. Görgü kurallarının değişmesi, yemek ve sofra adabının ortaya çıkması, konuşmanın "uygarlaşması" gibi değişiklikler saray toplumunun özelliklerini değiştirmiş, bu değişiklik duygulara da sirayet etmiştir.

Duyarlılık ve zarafet gibi duygu ve davranış şekillerine artan oranda önem verilmeye başlandığından bahseden Elias (2017, s.212); “belirli bir toplumsal duruma uygun olarak, önce üst tabaka arasında duygular ve duyulanım özellikleri değişmiş ve genel toplumun oluşumuyla birlikte, değişen bu duyulanım standardı bütün topluma yayılmıştır" demektedir. Elias'a göre Orta Çă̆g'da duygusallık her yere yayılmışken, modern çağda "uygarlaşma süreci" boyunca duyguları evcilleştirme ve dizginleme öğretilmiştir (Rosenwein, 2016, s.11). Toplumsal etkileşimlerde duyguları ve bastırılmamış heyecanları denetim altına almak ve düzenlemek üzere tavırlar icat edilmişti, sözü edilen olgular kamusal hayata müdahale ettikleri oranda, sıkı düzenlemeye tabi tutulmuştur (Mestrovic, 1999, s.195). Kontrol edilmeyen ve birden ortaya çıkan arzular ve güçlü duygular yerini iki kez düşünmeye ve davranışların belli sonuçları olabileceği gerçeğini hesaba katmaya mecbur bırakmıştır (Frevert, 2016, s.60). Elias buna "rasyonelleşme" adını vermektedir.

Rosenwein, Elias'ın bu görüşlerine katılmamaktadır. Tarihsel olarak hiçbir uygarlaşma ve rasyonelleşme süreci olmadığı sonucuna varan Rosenwein'a göre; yalnızca yeni koşullar altında eski unsurların yeniden düzenlenmesi, yeni amaçlara uygun hale getirilmesi ve tekrar birleştirilmesi söz konusudur (Rosenwein ve Cristiani, 2019, s.73). Rosenwein'a göre (2006, s.7) Elias psikologların dar bakış açısına yakalanmış, odağını süper egonun tarihselliği üzerine kaydırmış ve duygulanım (affect), dürtü (impulse) ve duygu (emotion) kavramlarını birbiri yerine kullanarak anlamların karışmasına sebep olmuştur. Orta Çağ / modern, kontrolsüz / ölçülü gibi iki uçlu anlayış yerine "duygu toplulukları" kavramını getirerek yeni bir anlatı paradigması kurmaya çalışan Rosenwein, Orta Çağ'da duyguların doğrudan ve dürtüsel olduğu fikrine karşı çıkmaktadır. Bu ikili yapıyı ortadan kaldırarak yeni 
bir duygu tarihini oluşturmanın yolu ise Orta Çağ ve modern uçurumu arasında köprü kurmaktan geçmektedir (Plamper, 2010, s.252).

\section{Biyolojik ve Evrensel Duygular}

Rasyonelleşmenin sahneye çıkmasıyla birlikte, duygular mantık zemininde değerlendirilmeye ve yorumlanmaya başlanmıştır. Amerikalı fizyolog ve filozof James (1884), bedeni ön plana çıkararak görece olarak duygulara farklı bir bakış açısı getirmeye meyletmiştir. Standart duygularla ilgili doğal düşünme biçimimizin bazı durumların zihinsel algısının, duygu denilen zihinsel duygulanımı harekete geçirdiğini ve bu zihin durumunun da bedensel ifadeye yansıması olduğunu söyleyen James (1884, s.189-190); bedensel değişikliklerin direkt olarak harekete geçirici durum algısını takip ettiğini ve bu değiş̧ikliklere karşı hissettiğimiz şeyin duygu olduğundan bahsetmektedir. Genel algiya göre, bir mirası kaybettiğimizde; üzülür ve ağlarız, bir ayı ile karşılaştığımızda korkar ve kaçarız, bir rakip tarafından aşağılandığımızda kızar ve saldırırız. Ancak James'e göre (1884, s.190); bu sıra doğru değildir, zihinsel bir durum hemen diğerine indirgenemez, bedensel tezahürler ilk olarak ikisinin arasında yer almalıdır, daha rasyonel olan durum üzgünüz çünkü ağlıyoruz, kızgınız çünkü saldırıyoruz, korkuyoruz çünkü titriyoruz olmalıdır. Dolayısıyla bu perspektife göre, fiziksel tepki duyguyu önceler ve durumun yargılanmasını dayanak alan belli biçimlerde yorumlanır (Lupton, 2002, s.29).

Devamında gelen çalışmalarda, duyguların daha seküler bir zeminde yer aldığı görülmektedir. Bu dönemde teolojik olan tüm teorik psikolojik metinlerin oranı azalarak hem seküler hem de bilimsel içerikleri artmış, psikolojik (ve diğer) sorulardaki kültürel ve akademik otorite, dini ve teolojik metinlerden ve kurumlardan daha seküler olanlara kaymıştır (Dixon, 2003, s.21). Bu bağlamda beden üzerindeki değişikliklere odaklanan Darwin, 1872 yılında yazdığı The Expression Of Emotion In Man And Animals isimli eserinde, duyguların milyonlarca yıldır süregelen evrimsel bir sürecin sonucunda oluştuğunu iddia etmiştir. Darwin için duygular evrenseldir, çünkü primatlardan Homo Sapiens'e kadar tüm hayvanlar için hayat mücadelesinde avantaj sağlamıştır 
(Plamper, 2015, s.82). Kedi, köpek, maymun gibi pek çok hayvanın duygusal ifadelerini insanlarınkiyle ilişkilendirerek incelediği çalışmasında Darwin, dünyanın dört bir yanındaki misyonerlere ve kaşiflere karşılaştıkları yerel halkların keder ya da heyecan gibi duyguları nasıl ifade ettiklerini soran anketler yollamıştır (Smith, 2018, s.17). İnsanlardaki sevinç, öfke, korku, iğrenme gibi duyguları yüz ifadeleri üzerinden inceleyen Darwin, kendi üzerinde de deneyler yapıp gülümsediğinde ya da titrediğinde kullandığı kasları belirlemeye çalışmıştır. Hatta küçük oğlu William'ı inceleyerek, "sekizinci gününden itibaren, çığlık atmasının belirtisi olarak kasılma nedeniyle kaşlarını çattığını gözlemledim" (Darwin, 2018, s.131) ifadelerini kullanarak tepkilerini kaydetmiştir. Darwin'e göre esas olan insanın hayatta kalma içgüdüsüdür. Böylece ifadeler veya duygu dili, kültür ve etnik kökene bakmaksızın tüm insanlarda bir tür iletişim oluşturur (Gökalp, 2019, s.105). Çalışmasının sonunda Darwin (2018, s.322); duyguların dilinin insanlığın refahı için kesinlikle önemli olduğunu kabul etmekle birlikte, etrafımızdaki insanların yüz ifadelerinin kaynağını ve kökenini anlamanın duyguları anlamak açısından elzem olduğunu savunmaktadir.

Duyguları ciddi ve bilimsel anlamda dikkate değer bir konu olarak gören Darwin'in bu yaklaşımı çok uzun yıllar sonra bile etkisini kaybetmemiş ve 1972 yılında Paul Ekman ${ }^{5}$ tarafından temel yüz ifadelerinin olduğu ve bunların da evrensel olduğu yönünde yapılan çalışma ile desteklenmiştir. Rosenwein ve Cristiani'ye göre (2018, s. 40); Darwin'in ve James'in çalışmaları düşünceden bağımsızdır ve bedensel fenomenlere dayanarak duyguların yaradılıştan geldiği iddiasını içermektedir. Lupton da (2002, s.26-27) duygular sosyolojisinin gerekliliği ve eksikliklerini sorguladığı çalışmasında Darwin'i “kalıtsal duygular"ın savunucularından biri olarak ele almakta ve Darwin'in duyguların insan gelişmesinin hayvansı mirası olduğu ve düşünce ile akla kıyasla itkilere daha fazla tabi olduğu şeklinde bir yaklaşım sergilediğini söylemektedir.

\footnotetext{
${ }^{5}$ Ayrıntılı bilgi için bkz. Ekman, P. (2003). Emotions Revealed, Recognizing Faces and Feelings to Improve Communication and Emotional Life. USA: Times Books.
} 


\section{Tarihsel Sosyoloji Perspektifinden Toplumsal ve Kültürel Duygular}

Duyguların doğuştan geldiği ve evrensel olduğuna yönelik baskın görüş, 20. yüzyılın başında duyguların toplumsal olarak ele alınmasıyla birlikte yerini farklı bakış açılarına bırakmıştır. Avustralyalı Aborijinlerin yaşamlarını din bağlamında inceleyen ve ritüelin grup yaşamındaki önemli yerini ortaya koyduğu çalışmasında Durkheim (2018a); dini ritüellerin insanları bir araya getirerek etkileşimi ve çeşitli duyguları oluşturduğu görüşünü ortaya koymuş ve bu duyguların "kolektif" olmasının önemine dikkat çekmiştir. "Kolektif coşku" olarak nitelendirdiği birlikte olma haliyle ilgili olarak Durkheim'ın işaret ettiği önemli noktalardan biri, toplum ve birey arasındaki etkileşimin kaçınılmazlığıdır. Duygular söz konusu olduğunda bireysel bağlamdan çok toplumsal bağlamı üzerinde durmuştur. Ona göre (2018b, s.31); "Eğer toplum belirli davranış biçimlerini ayıplıyorsa, bunun sebebi bu davranış biçimlerinin toplumun temel birtakım duygularını rencide etmesidir ve bu duygular da ayn bireyin duygularını onun fiziksel tabiatıyla ve zihinsel yapısıyla ilişkili olması gibi, toplumun yapısıyla ilişkilidir". Birey-toplum ilişkisini duygular açısından ele alan Durkheim, bu bağlamda "kolektif duygu" kavramından bahsetmektedir. Kolektif duygu ise, aslında her bir bireyin duygusunun, geri kalan bireyler tarafından oluşturulmasına işaret etmektedir (Durkheim, 2018b, s.63).

"Coşku" ya da "galeyan" olarak tanımlanan bu kolektif duyguların her zaman bireyin kendi duygulariyla uyumlu olmasa da var olmaya devam etmesinin mümkün olduğunu vurgulayan Durkheim (2018a, s.46), toplumsal olarak var olan duyguların bizden önce yerleşmiş olduğunu söylemekte ve bireyin üzerindeki topluluk baskısının ortadan kalktığı anda, kendisini "kaptırdığı" bu duygulardan uzaklaşabileceğini belirtmektedir. Durkheim'ın teorisinin en güçlü kısmı, incelediği mekanizmaların analizinde dayanışma ve kültürün oluşmasında yoğun duyguların ortaya çıkmasıdır (Summers-Effler, 2006, s.136).

1930'lu yıllarda duyguların önemine dikkat çeken ve toplumsal ilişkiler açısından ele alan bir başka isim, Annales Okulu tarihçilerinden Febvre'dir. Evrensel ve biyolojik bakış açısına çok uzun süre hapsolmuş duygulara gündelik hayatın ve insan ilişkilerinin içinde bakan Febvre, 
hislere daha fazla dikkat edilmesi yönünde çağrıda bulunması ve insan duygularının genişletilmesi için bir araştırma başlatmasına rağmen çağdaşları tarafından takip edilmemiştir (Frevert, 2018, s.35). Bununla birlikte Avrupa'da duygular tarihi çalışmaları, Annales Okulu'nun yaklaşımlarında temellenmiş ve Febvre tarafından temsil edilmiştir (Rosenwein, 2002, s.831). Longue durée $e^{6}$ yaklaşımını benimseyen Annales tarihçilerinden Marc Bloch, Fernand Braudel, Philippe Aries ve Roger Chartier, Febvre'in arkasından günlük faaliyetler, özel yaşam ve önceki nesillerin mentalitélerinin (zihniyetlerinin) tarihini araştırmışlar ve duyguların tarihsel araştırmasına öncülük etmişlerdir (Matt ve Stearns, 2014, s.3).

Febvre kendisini bir edebiyat tarihçisinden çok, çalıştığı dönemden kavram dünyasını anlatacak, bu dünyanın sistematiğine ışık tutacak çeşitli kaynaklar peşinde olan bir kültür tarihçisi olarak görmüştür (Faroqhi, 1985, s.151). Febvre dikkatini duygular -kendi deyimiyle hisler - tarihine çevirdiğinde, bunu keskin bir kültürel ve politik umutsuzluk hissiyle yapmıştır (Frevert, 2016, s.61). Onun jenerasyonu Avrupa uygarlığının düşüşüne, barbarca duyguların ve pratiklerin geri dönüşüne ve özgürlük, eşitlik ve dayanışma açısından hiç ilerleme olmamasına şahit olmuştur. Modern çağın doğmak üzere olduğu zaman ve yer olan 16. yüzyıl Avrupası'ndaki yaşam deneyimi onun tarafından yalnızca dört sözcükle kesin ve mükemmel bir şekilde özetlenmiştir: "Peur toujours, peur partout" ("Hep ve her yerde korku") (Febvre'den akt. Bauman, 2020, s.8). Umutsuzluk hissi ile yazdığı bu satırlarla Febvre'in, duyguların tarihsel gelişimine ve içinde bulunduğu dönemde geldiği noktaya bakmanın önemini vurguladı̆̆ 1 görülmektedir. Bu bağlamda, tarih ve sosyal bilimler arasındaki ilişkileri derinleştirmek amacıyla 1929 yılında kurduğu ve yönettiği Annales Economies Societes Civilisations dergisi halen yayın hayatına devam etmektedir.

İnsanlığın belli başı duygularının tarihçelerinin yazılması gerektiği doğrultusunda sik sik önerilerde bulunduğu halde, böyle bir işe girişmeyen Febvre'in bu davranışının, niceliksel çalışmalara duyduğu

\footnotetext{
6 Toplumsal yaşamın en temel yönlerini oluşturan ve insanlar ve dünya arasındaki uzun süredir devam eden, algılanamayacak kadar yavaş değişen ilişkilere odaklanan ve geçmişin derinliklerine uzanan tarihi perspektif. Kavram ilk olarak Fernand Braudel tarafından kullanılmıştır (Lexico 2020).
} 
ilgisizlikten kaynaklandığı söylenebilir (Faroqhi, 1985, s.153). Nitekim, evet-hayır şeklinde cevap verilmeye mahkûm edilmiş soruların yanlış ifade edildiğini söylemekte, özellikle "mutlu musunuz?" gibi duyguları içeren sorularda mutlak bir evet ya da hayır cevabının olamayacağını ileri sürmektedir (Febvre, 2010, s.115). “Duygusal yaşam her daim entelektüel yaşamın dişına taşar. Nefretin, korkunun, zalimliğin, aşkın tarihi gibi boş lakırdılarla bizi rahatsız etmeyi bırakın diyebilirsiniz. Ama bu boş lakırdılar, yarın evreni kokuşmuş cesetler çukuruna çevirecek" diyen Febvre, bahsettiği tüm "irrasyonel" duyguların beraber hareket ettiğini vurgulamaktadır (Rosenwein, 2002, s.822-823). Febvre, tarihçileri insan psikolojisini evrensel ve sürekli değil, akıcı ve tarihsel olarak olasılıklı görmeye çağırmıştır (Matt ve Stearns, 2014, s.3). Febvre'e göre duygular uygarlaşmış yaşamın bir parçası değildir, ama bu yaşamın oluşmasında önemli bir yere sahiptirler. Stearns ve Stearns (1985, s.816); duygular tarihine sosyolojik açıdan baktıkları çalışmalarında Febvre'i anmadan geçmemişler ve Febvre'in "psikolojik anakronizmi (kronolojik hata)" bırakmamız ve "çağın detaylı bir ruhsal donanımını kurmamız" için "tarihi psikoloji"nin gerekli olduğuna yönelik görüşlerini vurgulamışlardır.

\section{Duygunun Biricikleşmesi ve Duygusal Zekâ}

Duyguların zihin ve bedenin ötesine geçerek kültürel açıdan ele alınmasının ardından, tekrar bireysel alanda değerlendirilmesi 1960'lı ve 1970'li yıllara denk gelmektedir. 1960'lı yıllardaki bilişsel teoriler genel olarak bireye odaklanmış ve aynı olayda "eğer iki kişi değerlendirmelerinde farklılaşırlarsa" farklı duygulara sahip oldukları anlamına gelir bakış açısını benimsemişlerdir (Rosenwein ve Cristiani, 2018, s.40). 1970'li yıllara gelindiğinde ise filozoflar, sosyologlar ve psikologlar dikkatlerini toplumsal kurallar ve normlar tarafından idare edilen ve yönetilen çevreye yöneltmişlerdir. $\mathrm{Bu}$ nedenle, toplumsal inşacılar (ya da inşacılar) bazı toplulukların bir duyguya diğer topluluklardan daha fazla kıymet verdiğini ya da hiç vermediğini vurgulamışlardır (Rosenwein ve Cristiani, 2018, s.40). Bir kişinin hislerinin yaş, toplumsal cinsiyet, toplumsal sinif ve etnisiteye bağlanabileceği düşünceleri ortaya çıkmıştır. 1960-1975 yılları arasında 
yayınlanan kadınlar ve duygu ile ilgili 139 makalenin 125 (yani yüzde 89) kadarının depresyon ${ }^{7}$ duygusuyla ilgili olması (Rosenwein ve Cristiani, 2019, s.112) bunun bir örneğini oluşturmaktadır. Toplumsal bağlamlar ve dini inançların, tutku, arzu, iştah ya da sezgi olarak deneyimlenen şeyin gerçekte ne olabileceğine dair önemli çerçeveler sunabileceği düşünülmüştür (Frevert, 2016, s.56).

Duygular tarihi literatürünün bireysel çalışmalara kaymasıyla birlikte, aynı zamanda farklı topluluklar ve dil grupları arasında farklı duygu tanımlamaları olabileceği düşünülmeye başlanmıştır. Aslında, "İngilizce konuşan kültürlerin önemsiz bulduğu kimi duyguların diğer kültürler tarafından çok ciddiye alınabildiğgi" (Watt Smith, 2018, s.20) ortaya çıkmıştır ${ }^{8}$. Dillerin duygularla farklı ilişkiler içerisinde olduğu görülmüş ve şu sorular akla gelmiştir: "Eğer farklı insanlar duyguları farklı şekillerde kavramsallaştırıyorsa onları farklı şekilde de hissediyor olabilirler miydi? Kültürel değerler şahsi deneyimlerimize nasıl yansıyordu? Duygularımız gerçekten tamamıyla bize mi aitlerdi?" (Watt Smith, 2018, s.20-21). Bu tür sorularla birlikte, duygunun evrenselliği sorgulanarak, zaman, mekân, kültür, toplum gibi değişkenler hesaba katılmaya başlanmıştır. Bununla birlikte duygunun bireysel alandaki tezahürlerine daha fazla odaklanılmıştır.

Özellikle 1970'li yıllarla birlikte başlayan terapi dalgasıyla kendilik/benlik üstüne ciddi bir ilgi olmuş ve duygular bu bağlamda, bir anlamda merkeze oturmuştur. Harekete geçirici güçler olarak görülen yeni toplumsal hareketler keşfedilmiş, aynı zamanda din gibi baskıcı etkilerden ayrıştırılarak incelenmeye değer görülmüştür (Frevert, 2016, s.62). 20. yüzyılın ikinci yarısına doğru gelindiğinde, Batı dünyasında duygular hem özel alanda hem de kamusal alanda daha fazla önem kazanmaya başlamıştır. Özellikle, özel alanda duygular keskin bir şekilde öznel olarak değerlendirilmektedir. Bir kişinin hislerinin kişiye özel olduğu ve onu canll, insan, kendine özgü ve benzersiz yapan şeylerin duygular olduğundan bahsedilmektedir. 1960'lar ve 1970’lerde

\footnotetext{
7 İlerleyen yillarda depresyonu tıbbi bir hastaliktan ziyade, kültürel ve toplumsal bir fenomen olarak ele alan bir çalışmayı Ann Cvetkovich (2012) yapacaktı.

${ }^{8}$ Bu konuya dikkat çektiği çalışmasında Wierzbicka (2010), "mutluluk" kavramının anlamsal olarak farklılaşmasın incelemekte ve İngilizce'ye ve onunla gelen etnomerkezciliğe bă̆lanmadan duyguların ele alınması gerektiğini vurgulamaktadır.
} 
'benlik/kendilik' yeniden keşfedildiğinde kuşku duyulmayan tek şey; her şeyin ötesinde duygusal bir benlik olduğu görüşüdür (Frevert, 2018, s.37). Duygular bu nedenle bireyselliğin birincil işaretleri olarak görülmüştür.

İlerleyen dönemlerde toplumsal yaşam içerisinde oluşturulan standart duygular ve bireylerin hissettikleri arasında çeşitli farklılıklar olabileceği yönünde görüşler ortaya atılmıştır. Bu anlamda, 1985 yılında Stearns ve Stearns'in yazdığı makale, duygular tarihine yeni ve kapsamlı bir bakış açısı kazandırmıştır. Stearns ve Stearns'in "emotionology" (duygubilim) kavramı, bir toplumun duygusal standartların, bireylerin ya da grupların duygusal deneyimlerinden ayırmak için kullanılmıştır. $\mathrm{Bu}$ çalışma duygulara toplumsal anlamda bir dayanak sağlama açısından önemli bir konumu işgal etmektedir. Yazarlar, toplumsal inşacılıktan yararlanarak "insanların gerçekte nasıl hissettikleri" ile "duygusal dışavurumun standartlarını" birbirinden ayırmışlardır (Rosenwein ve Cristiani, 2019, s.16). İnsanların duygularını nasıl hissettikleri ya da yansıttıkları değil, daha ziyade insanların toplum arasında ağlamak, kızmak ya da fiziksel öfke göstermek gibi durumlarda ne düşündüğüyle ilgilenmişlerdir. Çalışma, insanların önünde sonunda hissedecekleri duygular hakkında ne düşündüklerini ele almaktadır (Rosenwein, 2002, s.824).

Duygubilim kavramının kabul edilen değerler ve duygusal deneyimi ayırmak için gerekli olduğunu söyleyen Stearns ve Stearns (1985, s.824), çalışmayı yapmaktaki amaçlarının toplumsal kurum ve kuruluşların bazı duygulara nötr ya da kayıtsız kalırken, diğerlerini nasıl ve neden desteklediğini ya da engellediğini ortaya çıkarmak olduğunu vurgulamışlardır. Onlara göre (1985, s.814), genellikle konuşulmasa ve tartışılmasa bile her toplumun kendine özgü duygusal standartları bulunur ve toplumlar özellikle bu standartlarda farklılaşırlar. Tarihçiler de artık duygu olayına ilgi duymaya başlamışlardır ve toplumların duygusal standartlarının zamanla ve sürekli değiştiği gözlemlenmiştir. Duygusal standartlardaki değişimler, toplumsal değişimin diğer yönlerini ortaya çıarabilir ve hatta bu değişime katkı sağlayabilir (Stearns ve Stearns, 1985, s.824).

$\mathrm{Bu}$ bakış açıları, duygunun birey-toplum etkileşimindeki yeri üzerinde daha fazla düşünülmesini sağlamıştır. Bu durum ise, 
duyguların bireysel anlamdaki öneminin vurgulanması ile sonuçlanmıştır. Özellikle yalnızca psikolojinin ve psikologların tekelinde gibi görülen algı kırılmaya başlamış, duygu ve zekanın birbirinden ayrılmak zorunda olmadı̆̆ı yönünde çalışmalar ortaya çıkmıştır. Goleman'ın 1995 yılında yazdığı çok satan kitabı Duygusal Zekâ (2018) bu alanda bir patlama yaşanmasına neden olmuştur. 40'tan fazla dile çevrilen ve 5 milyondan fazla satan kitap, yalnızca bireysel anlamda duyguların dikkate alınmasını sağlamakla kalmamıs, aynı zamanda ticari anlamda milyar dolarlık girişimlerin sahneye çıkmasına yardımcı olmuştur. Goleman'a göre (1995) duygusal zekâ, hayattaki sağlığımızı ve başarımızı belirlemede yardımcıdır ve kimi zaman entelektüel zekadan daha önemlidir. Tarihsel açıdan bakıldığında duygu ve aklın birbirinden keskin bir şekilde ayrıldığı dönemlerden, duygunun akıl ve zekayla birlikte anıldığı, hatta aklın duygusal yönünün olduğu bir bakış açısına geçildiği görülmektedir. Yönetim teknikleri içine dahil edilen duygusal zekâ pek çok ülkedeki insan kaynakları tarafından geniş çapta kullanılmıştır ve bugün de kullanılmaktadır (Frevert, 2018, s.37). Bu durum ise, duygunun ticarileşmesini beraberinde getirmiştir.

\section{Kapitalizm ve Duygular}

Teknolojinin ilerlemesi, küresel çapta firmaların ortaya çıkması, kurumların çalışanlardan beklentilerinin değişmesi ve iletişim araçlarının gündelik hayata nüfuz etmesiyle birlikte, duygunun bireylerin ve toplumların hayatlarındaki yeri değişiklik göstermiştir. Bildiğimiz anlamda bir iktidarın artık var olmadığını, onun yerine toplumlar için gerekli görülen disiplinin kapitalizmin duyguları kullanarak çeşitlilik üretme gücü tarafından sağlandığını belirten Massumi (2019, s. 24); bu şekilde en tuhaf duygulanımsal eğilimlerin bile para kaynağı oluşturdukları müddetçe kabul edilebilir hale geldiklerini vurgulamaktadır. Duyguların reklamlar tarafından kullanımıyla ilgili olarak Mestrovic (1999, s.85); reklamların artık ürünün özelliklerinden dahi bahsetmeyerek, duyguları sattığını söylemektedir. Bu bağlamda "duygusal emek" ve "duygusal kapitalizm" yaklaşımlarına yakından bakmak, manevi olanla anılan duygunun tarihi serüveni içerisinde 
maddi olanla nasıl yan yana gelerek, onun içinde eri(til)diğini görmek bakımından önemlidir.

\section{Duygusal Emek}

Sosyolog Hochschild'in literatüre armağan ettiği "duygusal emek" kavramı duygu çalışmalarına çok farklı bir boyut katılmasına yardımcı olmuştur. The Managed Heart (1983) isimli eserinde Hochschild, insan duygularının ticarileştirilmesini ele almıştır. Duygu ve toplumsal cinsiyet arasındaki ilişkiye odaklanan Hochschild, duygunun mantık ve akıl karşısına konumlandırılarak, algıyı parçaladığı ve insanların irrasyonel hareket etmesine yol açtı̆̆ına yönelik görüşü eleştirmektedir. "Toplumsal inşacı" bir perspektif izleyen Hocschild, bireylerin belirli durumlar karşısında ne hissedeceklerini ve duygularını nasıl ifade edeceklerini belirleyen ideolojiler, normlar, dağarcıklar ve diğer sembolik elementlerin yer aldığı bir duygu kültürünün toplum tarafından oluşturulduğunu söylemektedir (Turner, 2009, s.341). Ancak bu bakış açısında aynı zamanda duyguların biyolojik bir temeli olduğu düşüncesi de kendine yer bulmaktadır. Bazı duygular evrensel olabilir, hatta duyguların bazı ifadeleri de evrensel olabilir. Hocschild'in vurgulamak istediği, bu duyguların temelindeki biyolojik destek ne olursa olsun, insanlarm hissetmeleri ve ifade etmeleri gereken duyguların çoğunlukla kültür tarafından belirlendiğidir (Turner, 2009, s.342).

Hochschild, duygusal emek kavramın, kamusal olarak yüzsel ve bedensel görüntü oluşturabilmek için duyguların yönetimi anlamında kullanmaktadır. Ona göre duygusal emeğin bir değişim değeri mevcuttur çünkü bir ücret karşılığında satılmaktadır (Hochschild, 1983, s.7). Havayolu çalışanları ve host ve hosteslerle çalışma yapan Hochschild, "profesyonel" olma örtüsünün altına gizlenmiş ve çalışanlar için bir "değer" olarak vurgulanan "gülümseme"ye zorlanmayı araştırmış ve çalışanların yolcuları memnun edebilmek, rahatlatabilmek, endişelerini giderebilmek ve hiçbir sorun olmadığını vurgulayabilmek için yorgunluklarını ya da nasıl hissettiklerini tamamen dışarıda tutmak zorunda kaldıklarından bahsetmiştir. Toplumun "his kuralları" veya "duygu kuralları" dediği şeylerle çalışanlara duyguları ve ifadelerini 
kontrol ettirdiğinden ve insanlara nasıl hissetmesi, nasıl ifade etmesi ve toplumsal olarak hislerini nasıl baskılaması gerektiğini öğrettiğinden bahsetmektedir.

Duygusal emek kavramını duyguların performatifliği üzerinden değerlendirmesi, kabin uçuş ekibinin duygusal eğitiminin sonucu olarak başarılı adayların performe etmeleri söylenen duyguları içselleştirmesi anlamına gelmektedir (Rosenwein, 2016, s.6). Sinir bozucu yolculara gerçek manada gülümsemeyi ve kendi duygularını bastırmayı öğrenmişlerdir. Çalışanlar, bir uçakta çıkabilecek muhtemel sorunları önceden prova etmiş ve her birine uygun duygusal tepkiler geliştirmiştir (Mestrovic, 1999, s.279). Hava yollarında çalışan hosteslerin eğitim okullarında yalnızca gülümsemeyi değil, aynı zamanda yolcular onlara bağırdığında dahi cana yakın hissetmesi gerektiğinin öğretildiğini söylemektedir (Rosenwein, 2002, s.824). Ona göre bu iş ortamında gülümsemek geri kalan her şeyin önünde yer almaktadır ve çalışanlar "memnun" ya da "mutlu" görünmeye zorlanarak bir tür "duygusal emek" harcamaktadırlar. Duygusal yönetim 20. yüzyıl boyunca birey cephesinde değişim geçirdikçe daha az açik ve daha az iradi bir hale gelmektedir; dolayısıyla hisler ekonomik buyruklara koşumlanmıştır (Lupton, 2002, s.38). Her zaman kamusal hizmet işlerinin var olduğunu söyleyen Hochschild (1983, s.8), bu tür işlerin farkının toplumsal olarak tasarlanmış ve tamamen tepeden örgütlenmiş olması olduğunu belirtmektedir. Havayolu çalışanı olmak diğer işlerle kıyaslandığında, her ne kadar tatmin edici ücret ve sosyal statüye sahip olsa da çalışanın kendi emeği üzerindeki kontrolünü gittikçe azaltmaktadır. Hochschild'e göre (1983, s.9); duygusal emek potansiyel olarak iyidir. Çünkü hiç kimse asık suratlı bir garson, huysuz bir bankacı ya da istediğimiz bir şey olup olmadığını sormayan ve gözlerini kaçıran bir havayolu çalışanıyla karşılaşmak istemez. Burada aslında bizim görebileceğimiz şey ise; kamusal alandaki nezaketin ne denli kırılgan olduğudur. $\mathrm{Bu}$ kırılganlık elbette işin içerisine para girmesi ve bir emeğin satın alınmasına bağlıdır. 


\section{Duygusal Kapitalizm}

Duyguların ticarileştirilmesi ile ilgili günümüzde öne çıkan isimlerden bir diğeri Eva Illouz'dür. Illouz, Soğuk Yakınlıklar (2011) kitabında, meseleyi biraz daha ileri götürerek "duygusal kapitalizm"den bahsetmektedir. Illouz'ya göre (2011, s.15); toplumsal düzenlemelerin çoğu aynı zamanda duygusal düzenlemelerdir. Goleman'ın (1995) duygusal zekâ kavramıla birlikte, duyguların derecelendirilebilen, sinıflandırılabilen ve nicel olarak değerlendirilebilen kategoriler haline dönüştügüüü söyleyen Illouz (2011, s.98); bu şekilde bilişsel becerilerden çok duygusal becerilere dayanılarak elemanların sınıflandırılmasının ve buna bağlı olarak ücretlendirilmesinin yolunun açıldığının altını çizmektedir. Duygusal zekâ, kültürel ve sosyal sermayenin birleşme noktasında yer alan ve duygusal sermaye denilen yeni bir tür sermaye biçiminin edinilmesine yol açmıştır (Illouz, 2011, s.100).

Tüketim toplumlarının oluşmasının ardından duyguların satış üzerinde ne denli etkili olduğunun fark edilmesiyle birlikte, bunun bir satış amacı olarak kullanılması kaçınılmaz olmuştur. Çeşitli olumlu duygularla süslenen ürünlerin daha çok satılabileceği düşüncesinin hâkim olması, Illouz'ya göre aşkın da bundan nasibini almasını sağlamıştır. Illouz (1997) romantik aşk gibi duyguların nasıl ticarileştirildiği ve geniş bir nesneler ve ürünler yelpazesine bağlandığını işlemektedir. Kapitalizmin, herkesin ekonomik ve sembolik tüketim alanına katılımını mümkün kılarken, zenginliğin yoğunlaşması ve toplumsal bölünmelerin meşrulaştırılması yoluyla kendini sürdürdüğünü ve yeniden ürettiğini söyleyen Illouz (1997, s.2); modern romantizm tanımlarının ve uygulamalarının da tüketici kapitalizminin bu ikili doğası ile iç içe geçtiğini savunmaktadır. Ayrıca Illouz (2011, s.113), internetin duygulara etkisini aşk özelinde inceleyerek, internetin bedeni nasıl dönüştürdüğünü, daha açık bir dille teknolojinin bedeni ve duyguları nasıl yeniden ifade ettiğini sorunsallaştırmıştır.

\section{Tartışma ve Sonuç}

Duyguların birey ve toplum hayatındaki yeri geçmişten günümüze üzerinde durulan bir konu olmuştur. Duygu çok eskiden beri merak 
konusu olmuş ve çeşitli tanımlamaları ve anlamlandırmaları içinde barındırmıştır. Ruh-beden ya da duygu-akıl ikiliğinde genellikle dışlanan taraf olan duyguların ihmali, çeşitli felsefi düşünürlerin araştırma alanı olmuş, birey ve toplum arasındaki duygu etkileşimi incelenmeye ve tartş̧maya değer görülmüştür. Duyguların bireysel, doğuştan olduğunu düşünenlerin yanında, evrensel ve toplumsal olduğunu söyleyenler de bulunmaktadır. Bununla birlikte bugün kutsanan ve modern insanın sahip olması gerektiği düşünülen aşk, sevgi, mutluluk gibi duygulara olumlu özellikler atfedilirken, Orta Çă̆'a dönüldüğünde bazı duyguların kilisenin etkisi ile günah ve kaçınılması gereken ıstırap verici duygular olarak ele alındığı, aynı zamanda duygunun insan ruhu için gerekli olduğunu vurgulayanların da olduğu görülmektedir. Bu durum, duygunun yalnızca bireye özgü olmadığını ve tarihi, toplumsal olarak birey-toplum ilişkisi içerisinde karşıllıklı olarak değişip dönüştüğünü göstermektedir. Bu değişim ve dönüşümde ise, toplumsal hayat üzerinde etkili olan din, ekonomi, kültür gibi değişkenlerin ne denli önemli olduğu duyguların tarihsel sürecine bakıldığında anlaşılabilmektedir.

Duyguların eski çağlarda kontrol altında tutulması gereken şeyler olduğu, Orta Çağ dönemine gelindiğinde beden-ruh, akıl-duygu ikiliğinin görüldüğü, aynı zamanda duyguyu yaşamanın da insan olmanın bir gerekliliğgi olduğu yönünde görüşlere rastlanmaktadır. Duyguların tarihi açısından ortada olan şey; duyguların geçmişten günümüze ilgi çektiği ve üzerinde dikkatle durulan bir konu olduğudur. Başlarda duyguların insandan uzak tutulması gerektiği düşünülürken, 18. yüzyıla gelindiğinde duygusu olmayan insanın makineden farksız olduğu vurgulanarak, duyguya verilen kıymet gösterilmektedir. Modernleşme ile medeni olma/olmama kriterlerinden birine dönüşen duyguların anlamlarının değişmesi, günümüze doğru geldikçe duygunun bireye bırakılmayacak kadar önemli olduğuna dair görüşlerin artmasına neden olmuştur. Özellikle küreselleşme ve kapitalizmin yaygınlaşması ile duyguların ticarileşmesi, ürün ve içerik tedarikinden, ikili romantik ilişkilere değin geniş bir alanda duygunun kontrol altında tutulduğu ve manipüle edildiği anlamına gelmektedir.

Duyguların tarihine atılan bu kısa bakış, duyguların görünürlügünün tarihsel çizgisini kavrama ve geçmişten bugüne edindiği anlamları 
görme açısından önem arz etmektedir. Frevert (2016, s.53), bu tür çalışmaların yapılmasıyla ilgili olarak, daha çok sosyolojik, ekonomik, kültürel ve siyasi tarih göz önünde bulundurularak, duyguların karışık kompozisyonları, anlamları ve pratiklerine 1şık tutulması gerektiğini söylemektedir. Önceleri dinin tekelinde olan duyguların, sonrasında uzun yıllar felsefe ve psikoloji alanına sıkışması, daha sonra ise antropologlar, tarihçiler ve sosyologların çalışma konusu haline gelmesi bu alanda yapılan - ve yapılacak - çalışmaların bir gereklilik olduğunu göstermektedir. Özellikle günümüz teknolojilerinden olan sosyal ağlardaki "beğen" ve "paylaş" ekonomileri üzerine kurulan duygu tezahürleri, duygunun gelecekte alacağı anlamları ve bunların bireysel ve toplumsal temelde ne tür değişikliklere yol açacağını düşünmeye sevk etmektedir. 


\section{EXTENDED ABSTRACT}

\section{The Historical Adventure of Emotions and Emotions in History \\ * \\ Şeyda Koçak Kurt \\ Hacı Bayram Veli University}

Emotions have been the subject of various studies for many years. When the emotion literature is examined, it is seen that there is no single definition of emotion. For example; between 1872 and 1980, ninety-two different emotion definitions were used only in English experimental psychology (Plamper 2015, p.11). Lack of a common view on the conceptual use of emotion does not mean that emotion has not been emphasized since ancient times. Therefore, even under different concepts and meanings, emotions have always been the subject of curiosity and research from different disciplines such as philosophers, psychologists, sociologists, anthropologists and historians.

When looking at the ancient Greece era, it is seen that the emotion category is a part of Western languages. In this period, the mind-soul dichotomy is at the forefront, the soul is mentioned rather than the emotions, and the soul's desires are associated with the body. In this period, it is recommended to stay away from some spiritual desires and pleasures that will prevent access to information by keeping the mind integrated with knowledge which is being thought above everything else. The Middle Ages that follow can be described as a period in which emotions both come to light and are tried to be suppressed as much. It is a period in which the perception of logic-man, emotion-woman dichotomies are also emphasized. When examined periodically, it is clearly seen that the invisibility of emotions is no longer in question. However, this time, it is witnessed that emotions enter to the field of religion and cannot leave from it.

In the Age of Enlightenment, the prominence of reason and science led to the distinction between emotions and reason to become sharper and to see emotions as obstacles to logic. In the Middle Ages, some passions and emotions were seen as deadly sins that harm and sick the 
body, while in the Enlightenment period, body came to the fore as the place where emotions were found. Subsequent studies focused on changes in the body in order to put emotions on a more secular basis. Darwin (2018) claimed that emotions were the result of an evolutionary process that had lasted millions of years. This led to a universal and biological perspective.

Afterwards, emphasis was placed on the social and cultural aspects of emotions. Especially Febvre and the historians of Annales School have emphasized the importance of emotions in daily life relationships. After the emotions are considered culturally by going beyond the mind and body, the re-evaluation in the individual field corresponds to the 1960s and 1970s. With the individualization of emotions during these years, it has begun to be thought that there may also be different emotion definitions between different communities and language groups. As we get closer to today, emotions have started to attract more individual attention. Especially the perception, which seems to be in monopoly of only psychology and psychologists, has started to break, and studies have emerged the emotion and intelligence do not have to be separated from each other. Emotional intelligence, which is included in management techniques, has been widely used by human resources in many countries and is still used today (Frevert, 2018, p.37). This situation leads to commercialization of emotion. In this context, the concepts of emotional labor and emotional capitalism have come to the fore and emotions have become out of question-free from technological and global developments.

This brief overview of the history of emotions is important in terms of understanding the historical line of the visibility of emotions and seeing the importance which has gained from past to present. However the concepts of emotion do not differ historically, it is seen that the meanings of emotion have changed in the historical process. The commercialization of emotions, especially with globalization and the spread of capitalism, means that emotion is kept under control and manipulated in a wide range from product and content supply to bilateral romantic relationships.

It has been found that emotion is not peculiar to the individual and its history has been reciprocally changed and transformed within the 
individual-society relationship. In this change and transformation, the importance of variables such as religion, economy, and culture that have an important impact on social life can be understood by looking at the historical process of emotions.

The fact that emotions, which were previously in the monopoly of religion and stuck in the field of philosophy and psychology for many years, and later became the subject of study of anthropologists, historians and sociologists, shows that the work which was done - and to be done - in this field is a necessity. Spesifically the manifestations of emotions built on "like" and "share" economies in social network sites, which are one of today's fundamental technologies, make one think about the future meanings of emotion and what kind of changes it will lead to on individual and social basis.

\section{Kaynakça / References}

Ahmed, S. (2014). Duyguların kültürel politikası. (Sultan Konut, Çev.). İstanbul: Sel Yayınları.

Augustine. (2010). Confessions. USA: Westminster Press.

Aristoteles, (2019a). Magna moralia, erdemler ve kötü huylar. (Y. Gurur Sev, Çev.). İstanbul: Pinhan Yayıncllık. 2019.

Aristoteles (2018). Poetika şiir sanatı üstüne. (Samih Rifat, Çev.). İstanbul: Can Yayınları.

Aristoteles (1995). Retorik. (Mehmet H. Doğan, Çev.). İstanbul: YKY. 1995.

Aristoteles (2019b). Ruh üzerine. (Ömer Aygün, Y. Gurur Sev, Çev.). İstanbul: Pinhan Yayıncllı. 2018.

Baker, U. (2014). Kanaatlerden imajlara duygular sosyolojisine doğru. (Harun Abuşoğlu, Çev.). İstanbul: Birikim Yayınları. 2010.

Bauman, Z. (2020). Akışkan korku. (Cumhur Atay, Çev.). İstanbul: Ayrıntı Yayınları. 2020.

Boym, S. (2009). Nostaljinin geleceği. (Ferit Burak Aydar, Çev.). İstanbul: Metis Yayınları. 2009.

Brownmiller, S. (2013). Femininity. New York: Open Road Integrated Media.

Cluzeau, F. (2013). Platon'un ruh kuramı'nda pathos. Cedrus, I, 65-87.

Cvetkovich, A. (2012). Depression: A public feeling. London: Duke University Press. 
C. Nussbaum, M. (1978). Aristotle's de motu animalium. Princeton: Princeton University Press.

Darwin, C. (2018). The expression of the emotions in man and animals. Ankara: Gece Kitaplığı.

Descartes, R. (2017a). Duygular ya da ruh halleri. (Çiğdem Dürüşken, Çev.). İstanbul: Alfa Basım Yayın Dağıtım. 2017.

Descartes, R. (2017b). Felsefenin ilkeleri. (Mesut Akın, Çev.). İstanbul: Say Yayınları. 2017.

Dixon, T. (2012). Emotion: The history of a key word in crisis. Emotion Review, 4(4), 338-344.

Dixon, T. (2003). From passions to emotions the creation of secular psychological category. UK: Cambridge University Press.

Durkheim, E. (2018a). Dini hayatın ilkel biçimleri. (Fuat Aydın, Çev.). İstanbul: Eski Yeni Yayınları. 2018.

Durkheim, E. (2018b). Sosyolojik yöntemin kuralları. (Özcan Doğan, Çev). İstanbul: Doğu Batı Yayınları. 2018.

Eco, U. (2007). Gülün adı. (Şadan Karadeniz, Çev.). İstanbul: Can Yayınları.

Ekman, P. (2003). Emotions revealed, recognizing faces and feelings to improve communication and emotional life. New York: Times Books.

Elias, N. (2017). Uygarlık süreci, sosyo-oluşumsal ve psiko-oluşumsal incelemeler, cilt 1 batılı dünyevi üst tabakaların davranışlarındaki değiş̧imler. (Ender Ateşman, Çev.).. İstanbul: İletişim Yayınları. 2017.

Faroqhi, S. (1985). Duyguların da bir tarihçesi vardır: Lucien Febvre'in yapıtları. (İsen Arıcanlı, Latife Özkaramete, Çev.). Toplum ve Bilim, $28,149-162$.

Febvre, L. (2010). Gündelik hayatın eleştirisi II. (Işsk Ergüden, Çev.). İstanbul: Sel Yayıncilik. 2010.

Frevert, U. (2018). Historicizing emotions. Carolyn Price, Eric A. Walle (Der.). ISRE's Sourcebook for Research Emotion and Affect içinde (s.3439). USA: ISRE Press.

Frevert, U. (2016). The history of emotions. Lisa Feldman Barrett, Michael Lewis ve Jeanette M. Haviland-Jones (Der.). Handbook of Emotions 4th Edition içinde (s.49-65). New York: The Guilford Press.

Frevert, U. (2014). The modern history of emotions: A research center in Berlin. Cuadernos de Historia Contemporanea, 36, 31-55.

Goleman, D. (2018). Duygusal zekâ. (Banu S. Yüksel, Çev.). İstanbul: Varlık Yayınları. 2018. 
Gökalp, N. (2019). Duygu felsefesi. Ankara: Atlas Kitap.

Hochschild A. R. (1983). The managed heart commercialization of human feeling. USA: University of California Press.

Illouz, E. (1997). Consuming the romantic utopia, love and the cultural contradictions of capitalism. USA: University of California Press.

Illouz, E. (2011). Soğuk yakınlıklar duygusal kapitalizmin şekillenmesi. (Özge Çağlar Aksoy, Çev.). İstanbul: İletişim Yayınları. 2011.

James, W. (1884). What is an emotion?. Mind, 9(34), 188-205.

Joshanloo, M. (2013). Eastern conceptualizations of happiness: Fundamental differences with Western views. Journal of Happiness Studies, 15, 475493.

Konstan, D. (2018). Emotions in history: The beginnings. Carolyn Price, Eric A. Walle (Der.). ISRE's Sourcebook for Research on Emotion and Affect içinde (s.46-50). USA: ISRE Press.

Konstan, D. (2006). The emotions of the ancient Greeks: Studies in Aristotle and classical literature. Canada: University of Toronto Press.

Lexico (2020). Meaning of longue durée in English. 24.01.2020 tarihinde https://www.lexico.com/definition/longue_duree adresinden erişildi.

Lupton, D. (2002). Duygusal yaşantı. (Mustafa Cemal, Çev.). İstanbul: Ayrıntı Yayınları. 2002.

Lutz, C. (1987). Goals, events, and understanding in Ifaluk emotion theory. N. Quinn ve D. Holland (Der). Cultural Models in Language and Thought içinde (s.471-484). New York: Guilford.

Massumi, B. (2019). Devinimlerde Seyretmek. (Can Öztürk, Çev.). Ayrıntı Dergi, 30, 15-34.

Matt, S. J. and Stearns, P. N. (2014). Introduction. Doing Emotions History içinde. (s.1-16). USA: University of Illinois Press.

Mestrovic, S. G. (1999). Duyguötesi toplum. (Abdullah Yılmaz, Çev.). İstanbul: Ayrıntı Yayınları. 1999.

Mills, W. (2016). Sosyolojik tahayyül. (Ömer Küçük, Çev.). İstanbul: Hill Yayınları. 2016.

Oatley, K. (2004). Emotions a brief history. UK: Blackwell Publishing.

Plamper, J. (2010). The history of emotions: An interview with William Reddy, Barbara Rosenwein, and Peter Stearns. History and Theory, 49, 237-265. 
Plamper, J. (2015). The history of emotions, an introduction. (Keith Tribe, Çev.). USA: Oxford University Press. 2015.

Price, A. W. (2009). Emotions in Plato and Aristotle. Peter Goldie (Der). The Oxford Handbook of Philosophy of Emotion içinde (s.121-141). New York: Oxford University Press.

Reddy, W. M. (2004). The navigation of feeling, a framework for the history of emotions. UK: Cambridge University Press.

Rosenwein, B. H. (2006). Emotional communities in the early middle ages. London: Cornell University Press.

Rosenwein, B. H. (2016). Generations of feeling, a history of emotions 600-1700. USA: Cambridge University Press.

Rosenwein, B. H. (2002). Worrying About Emotions in History. The American Historical Review, (107)3, 821-845.

Rosenwein, B. H. ve Cristiani, R. (2019). Duygular tarihi nedir?. (Kemal Özdil, Çev.). İstanbul: Islık Yayınları.

Rosenwein, B. H. and Cristiani, R. (2018). Old and new in the history of emotions. Carolyn Price, Eric A. Walle (Der.). ISRE's Sourcebook for Research Emotion and Affect içinde (ss. 40-45). USA: ISRE Press. 40-45.

Stearns P. N. and Stearns, C. Z. (1985). Emotionolgy: Clarifying the history of emotions and emotional standards. The American Historical Review, 90(4),813-836.

Summers-Effler, E. (2006). Ritual theory. Jan E. Stets, Jonathan H. Turner (Der.). Handbook of the Sociology of Emotions içinde (ss. 135-154). USA: Springer.

Tenhouten, W. D. (2007). A general theory of emotions and social life. USA: Routledge.

Toohey, P. (2014). Can sikıntısının eğlenceli tarihi. (Zeynep Koçak Yılmaz, Çev.). İstanbul: Doğan Kitap. 2014.

Turner, J. H. (2009). The sociology of emotions: Basic theoretical arguments. Emotion Review, 1(4), 340-354.

Watt Smith, T. (2018). Duygular sözlüğü acımadan zevklenmeye. (Hale Şirin, Çev.). İstanbul: Kolektif Kitap. 2018.

Watt Smith, T. (2020). Schadenfreude, başkasının talihsizliğinden duyulan keyif. (Nüvit Bingöl, Çev.). İstanbul: Kolektif Kitap. 2020.

Wierzbicka, A. (2010). The "History of Emotions" and the Future of Emotion Research. Emotion Review, 2(3), 269-273. 
Kaynakça Bilgisi / Citation Information

Koçak Kurt, Ş. (2021). Duyguların tarihsel serüveni ve tarihte duygular. OPUS-Uluslararası Toplum Araştırmaları Dergisi, 18(40), 2821-2852. DOI: $10.26466 /$ opus.876932. 